Article

\title{
Phytochemical Compounds of Branches from P. halepensis Oily Liquid Extract and S. terebinthifolius Essential Oil and Their Potential Antifungal Activity
}

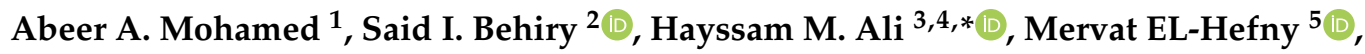 \\ Mohamed Z.M. Salem ${ }^{6, *(D)}$ and Nader A. Ashmawy ${ }^{7}$ (D) \\ 1 Plant Pathology Institute, Agriculture Research Center (ARC), Alexandria 21616, Egypt; \\ abeer_pcr@yahoo.com \\ 2 Agricultural Botany Department, Faculty of Agriculture (Saba Basha), Alexandria University, \\ Alexandria 21531, Egypt; behiry_2006@yahoo.com \\ 3 Botany and Microbiology Department, College of Science, King Saud University, P.O. Box 2455, \\ Riyadh 11451, Saudi Arabia \\ 4 Timber Trees Research Department, Sabahia Horticulture Research Station, Horticulture Research Institute, \\ Agriculture Research Center, Alexandria 21526, Egypt \\ 5 Department of Floriculture, Ornamental Horticulture and Garden Design, Faculty of Agriculture (El-Shatby), \\ Alexandria University, Alexandria 21545, Egypt; mervat.mohamed@alexu.edu.eg \\ 6 Forestry and Wood Technology Department, Faculty of Agriculture (EL-Shatby), Alexandria University, \\ Alexandria 21545, Egypt \\ 7 Department of Plant Pathology, Faculty of Agriculture (El-Shatby), Alexandria University, \\ Alexandria 21545, Egypt; nader_pcr@yahoo.com \\ * Correspondence: hayhassan@ksu.edu.sa (H.M.A.); zidan_forest@yahoo.com (M.Z.M.S.)
}

Received: 28 January 2020; Accepted: 6 March 2020; Published: 11 March 2020

\begin{abstract}
In the present study, the antifungal activity of wood treated with Pinus halepensis branch $n$-hexane oily liquid extract (OLE) and Schinus terebinthifolius branch essential oil (EO) was evaluated against the growth of four phytopathogenic fungi-Bipolaris oryzae, Fusarium oxysporum, Fusarium solani, and Rhizoctonia solani. Air-dried wood samples of Pinus roxburghii were autoclaved, and each wood received $100 \mu \mathrm{L}$ of the concentrated oils from $P$. halepensis and S. terebinthifolius. The main compounds identified in S. terebinthifolius branch EO were terpinen-4-ol $(18.25 \%)$, cis- $\beta$-terpineol $(15.60 \%), \gamma$-terpinene $(12.46 \%)$, sabinene $(9.83 \%), \alpha$-terpinene $(8.56 \%)$, and 4-thujanol (6.71\%), while the main compounds in P. halepensis branch HeO were 2-undecenal (22.25\%), 4-hydroxy-10-methyl-3,4,7,8,9,10-hexahydro-2H-oxecin-2-one (8.43\%), (Z)-2-decenal (6.88\%), nonanal (5.85\%), (2E)-2-decenal (4.65\%), (E,E)-2,4-decadienal $(4.41 \%)$, arachidonic acid methyl ester $(4.36 \%)$, and 2-(7-heptadecynyloxy)tetrahydro-2H-pyran (4.22\%). P. halepensis OLE at a concentration of $3 \%$ showed the highest inhibition percentage of fungal growth (IPFG) of B. oryzae, followed by S. terebinthifolius EO at $3 \%$ and $2 \%$, with IPFG values of $80 \%, 74.44 \%$, and $71.66 \%$, respectively. At a concentration of $3 \%$, branch oils from $S$. terebinthifolius and P. halepensis were found to have the highest IPFG values with $45.55 \%$ and $40.55 \%$, respectively, against F. oxysporum growth. Moderate to weak activity was found against $F$. solani when S. terebinthifolius EO and P. halepensis OLE were applied to wood. EO and OLE-treated wood samples at 3\% produced inhibitions of $54.44 \%$ and $41.11 \%$, respectively, against $R$. solani.
\end{abstract}

Keywords: essential oil; oily liquid extract; P. halepensis; S. terebinthifolius; fungi; wood bio-fungicide 


\section{Introduction}

Natural products extracted from forestry trees have a sustainable source of natural products from their different parts (wood, bark, roots, leaves, flowers, branches, seeds, and fruits). These natural products, such as essential oils (EOs), fixed oils, and polyphenolic and flavonoid compounds, have great effects in terms of their antimicrobial activities [1-9].

Bipolaris oryzae is the causal agent of rice brown spot disease and is responsible for significant economic losses, and in Egypt the disease is ranked second, coming next after blast disease [10]. Fusaria are common soil saprophytes; however, they are also known as phytopathogens-especially Fusarium oxysporum - that cause root or blight diseases in many host plants [11-13]. Two Fusarium species were recently included in the list of the top ten plant pathogenic fungi with both economic and scientific importance, with one of them being F. solani, which causes vascular wilt or root rot in more than 100 plant species [14,15]. Rhizoctonia solani is considered a distractive soil-borne disease of rice production worldwide, causing rice sheath blight disease. The initiation of an integrated disease management procedure is important to keep the disease under control [16].

Phytochemicals from all of the parts of Aleppo pine, P. halepensis Miller, have shown the presence of EOs, phenolic compounds, turpentine, and terpenes with valuable medicinal uses and antimicrobial agents [9-21]. Needle EOs have been shown to have many bioactive compounds, such as $\alpha$-humulene, aromadendrin, and $\beta$-caryophyllene [22]; caryophyllene oxide, myrcene, $\alpha$-pinene, and $\beta$-caryophyllene were also identified $[23,24]$.

Schinus terebinthifolius Raddi produces resin that contains monoterpenes acting as a defense against attacking pathogenic agents [25]. Extracts and EOs, especially from fruits, have been studied extensively in dozens of works, e.g., oleic acid, $\delta$-cadinene, $\alpha$-phellandrene, $1 \mathrm{~b}, 5,5,6 \alpha$-tetramethyloctahydro- $6 \mathrm{H}$-indeno[1,2-b]oxiren-6-one, aromadendrene, hexadecanoic acid-2,3-dihydroxypropyl ester, $\alpha$-caryophyllene, and germacrene $\mathrm{D}$ were the main compounds found in the ethyl ether extract of $S$. terebinthifolius fruits with good antifungal activity against T. harzianum and A. niger [2]. Acetone extract from ripened fruits with oleic acid, $\alpha$-phellandrene, and $\delta$-cadinene as main compounds had observed antibacterial activity [26]. Other compounds such as flavonoids, phenols, tannins, anthraquinones, quercetin, kaempferol, biphenyl esters, and steroids were isolated from the fruits of S. terebinthifolius [27-31], with potential antimicrobial activities. Methanol and Aqueous extracts of $S$. terebinthifolius showed potential activity against C. albicans [32,33]. Extracts of the stem of the plant showed the isolated compounds of schinol

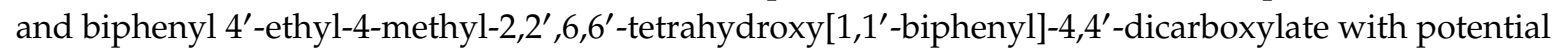
antifungal activity against $P$. brasiliensis [34].

Lignocellulosic materials such as wood can be affected or deteriorated by fungi in moist conditions, causing a loss in the overall quality or the surface quality of the wood, as well as some environmental problems as a result of their excretion of toxins [35-38]. Some works have been carried out to preserve or protect some commercial wood species from deterioration by fungi using natural extracts, and the results showed good antifungal activity, either inhibiting or preventing their growth $[2,3,7,8]$. No fungal growth of A. tenuissima and F. culmorum occurred on the Acacia saligna wood surface treated with the methanol extract of Maclura pomifera bark [39]. Recently, the treated wood samples of Melia azedarach with the water extract of $A$. saligna flowers, the ethanol extract of Musa paradisiaca peels, the n-hexane oily extracts from Eucalyptus camaldulensis and Vitex agnus-castus, or with Withania somnifera fruit acetone extract showed good antifungal activity against several molds, such as F. culmorum, $P$. chrysogenum, and R. solani $[3,7,8,40]$. Furthermore, new green pesticides that act as alternatives, such as natural product-based pesticides, are being developed to replace compounds lost due to the new regulations [41].

EOs are an interesting option for use as new pesticides reserving as anti; fungi, insects, and weeds. Moreover, many EOs can directly act as a natural insect repellent to provide protection against mosquitoes and other harmful arthropods, or to provide antifeedant activity against herbivores, such as eucalyptus oil $[42,43]$. MyggA ${ }^{\circledR}$ or Natural or Citriodiol ${ }^{\circledR}$ and Buzz away are other mosquito 
repellent products based on p-Menthane-3,8-diol and citronellal monoterpene extracted from lemon eucalyptus E, which are marketed to use against public health pests and can help avoid ticks or biting flies [44-47]. Many researchers have reported that EO applications should be considered as resistance inducers and could affect pathogens through the production of phytoalexins and biochemical plant defense [48]. Indeed, even little amounts of EOs applied on plants in vivo have been shown to produce a greater reduction in disease severity [49]. There are many reasons that may contribute to the greater effect of EOs in vivo than in vitro, such as variation of the optimum temperature of fungal growth and the presence of microorganisms on the plant surface [50]. The present work aimed to evaluate the bioactivity of $P$. halepensis n-hexane oily liquid extract and S. terebinthifolius essential oil as wood-biofungicides.

\section{Materials and Methods}

\subsection{Preparation of Essntial Oil and n-Hexane Oily Liquid Extract}

Green branches (wood and bark) of Brazilian Peppertree, Schinus terebinthifolius Raddi (Anacardiaceae), were rapidly washed by tap water to remove the dust, then smoothly dried with paper towel and cut into small pieces. About $100 \mathrm{~g}$ of the cut branches underwent extraction of their essential oil (EO) using the hydrodistillation method of the Clevenger apparatus for $3 \mathrm{~h} \mathrm{[51].}$ Meanwhile, the green branches (wood and bark) of Aleppo pine, Pinus halepensis Miller (Pinaceae), after being cut into small pieces, underwent extraction via the soaking method, where about $100 \mathrm{~g}$ of the branch sample was soaked in $n$-hexane solvent $(200 \mathrm{~mL})$ for $6 \mathrm{~h}$ under shaking. The $n$-hexane oily liquid extract (OLE) was separated by filtration with Whatman No. 1 filter paper under suction pressure then the OLE concentrated by evaporating the n-hexane solvent under vacuum using a rotary evaporator at $45^{\circ} \mathrm{C}$. EO and OLE were stored in brown tubes until use.

\subsection{The Antifungal Activity of Wood Treated with Essential Oil and Oily Lquid Extract}

Wood samples of $P$. roxburghii Sarg were prepared at the approximate dimensions of $2 \times 1 \times 0.5 \mathrm{~cm}$, autoclaved at $121{ }^{\circ} \mathrm{C}$ for $20 \mathrm{~min}$, and then left to cool. The four fungi of Bipolaris oryzae, Fusarium oxysporum, Fusarium solani, and Rhizoctonia solani were used for the bioassay. S. terebinthifolius (EO) and P. halepensis (OLE) were prepared at the concentrations of $1 \%, 2 \%$, and $3 \%$. For every wood sample, $100 \mu \mathrm{L}$ of the concentrated EO or OLE was applied. The antifungal activity of the treated wood samples was compared with wood samples without oil treatments, which were used as a control. The fungal inhibition percentage was calculated with the formula of inhibition percentage of fungal growth (IPFG) $(\%)=\left[\frac{\mathrm{DC}-\mathrm{DT}}{\mathrm{DC}}\right] \times 100$, where DC is the diameter of fungal control and DT is the diameter of treatment. Four replicates were carried out for all of the treatments. The antifungal activities of the treated wood were measured following the method of our previous works [3,52-55] with minor modification, namely, ensuring that each wood sample examined for its antifungal activity had received the tested amount of EO or OLE.

\subsection{Gas Chromatography-Mass Spectrometry (GC/MS) Analysis of the EO and OLE}

The chemical compositions of the EO and OLE were analyzed using the Focus GC-DSQ Mass Spectrometer (Thermo Scientific, Austin, TX, USA) with a direct capillary column TG-5MS $(30 \mathrm{~m} \times 0.25 \mathrm{~mm} \times 0.25 \mu \mathrm{m}$ film thickness) apparatus at the Atomic and Molecular Physics Unit, Experimental Nuclear Physics Department, Nuclear Research Centre, Egyptian Atomic Energy Authority, Inshas, Cairo, Egypt. The column oven temperature was initially held at $45^{\circ} \mathrm{C}$, and then increased by $5{ }^{\circ} \mathrm{C} / \mathrm{min}$ to $200^{\circ} \mathrm{C}$, held for $5 \mathrm{~min}$, then increased again to $300^{\circ} \mathrm{C}$ by $5^{\circ} \mathrm{C} / \mathrm{min}$. Other conditions and identification of the compounds using the WILEY 09 and NIST 14 mass spectral databases can be found in previous works $[1-5,56,57]$. 


\subsection{Statistical Analysis}

Data of the antifungal activity were statistically analyzed with two factors [(type of oil (EO and OLE) and the concentration)] using the SAS system [58]. The differences among the means of the treatments were recorded using Fisher's least significant difference $\left(\mathrm{LSD}_{0.05}\right)$.

\section{Results}

\subsection{Visual Observations of the Fungal Growth}

Figure 1 shows the antifungal activity of the treated Pinus roxburghii wood with the $n$-hexane oily extract (OLE) from Pinus halepensis and the essential oil (EO) of S. terebinthifolius against the growth of Bipolaris oryzae. In the control treatment (wood without EO or OLE), the fungal growth almost reached full linear growth, but for the wood treated with both oils, the fungal mycelia were suspended and the inhibition was found at all of the concentrations used (1\%,2\%, and $3 \%)$. Additionally, the fungal growth was found to grow on the side opposite to the treated wood with both EO and OLE.

B. oryzae with control wood
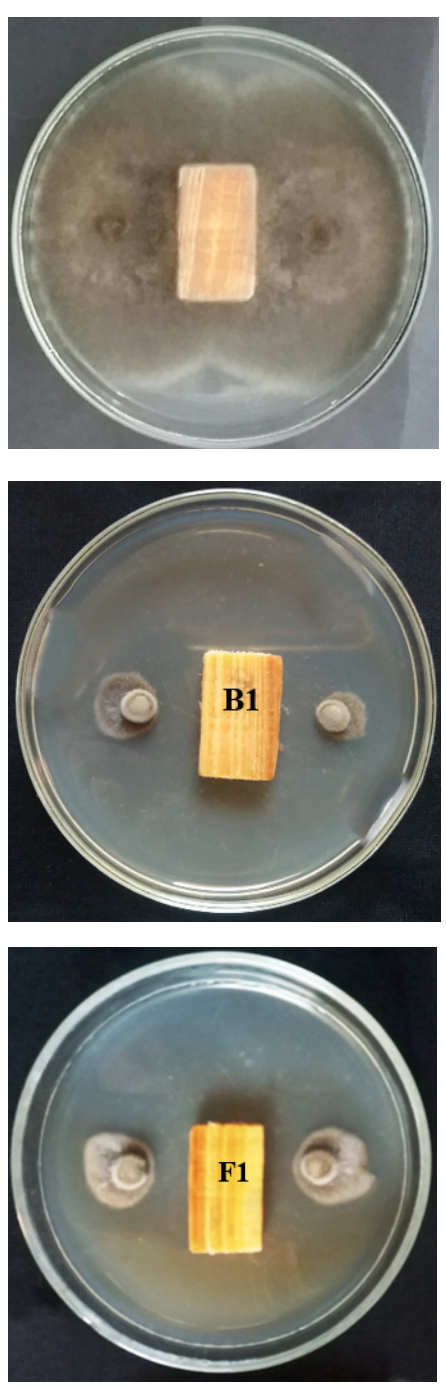

B. oryzae growth
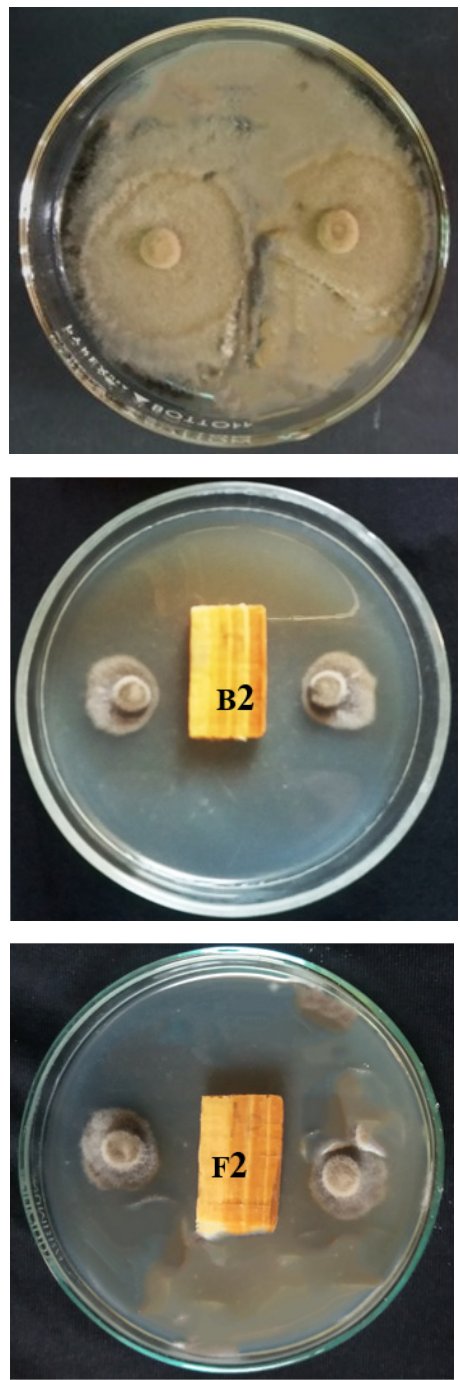

B. oryzae
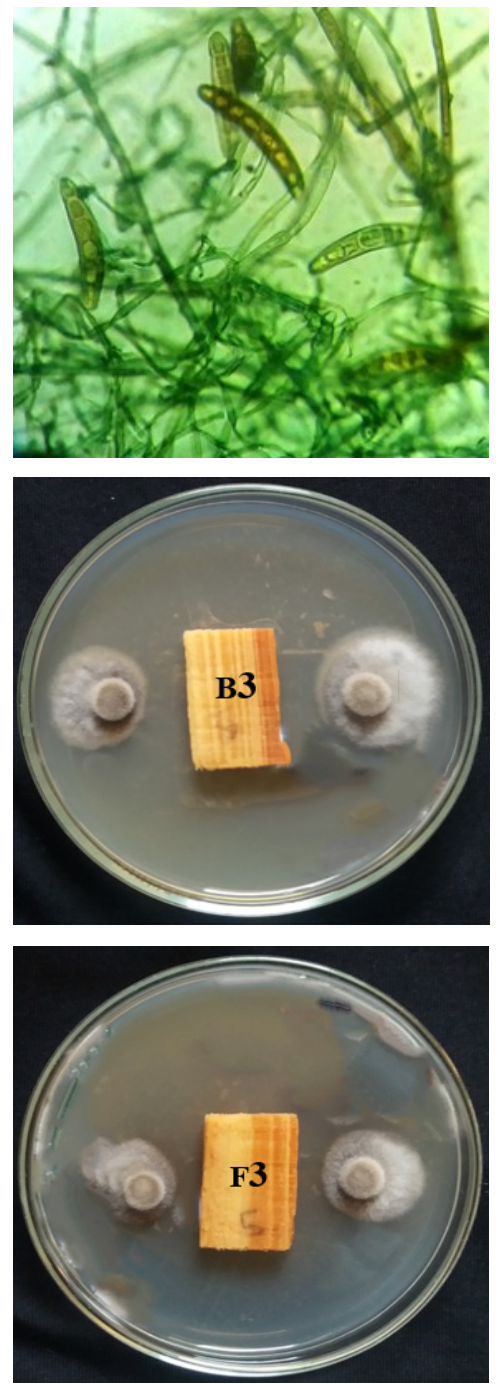

Figure 1. Antifungal bioassay of wood treated with (B) P. halepensis oily liquid extract (OLE) and (F) $S$. terebinthifolius essential oil (EO) against the growth of B. oryzae. B1: 3\%; B2: 2\%; B3: 1\%; F1: 3\%; F2: 2\%; F3: $1 \%$. 
Compared to the control condition, Fusarium oxysporum growth was inhibited and did not reach the treated wood with both EO and OLE, especially at the concentrations of 2\% and 3\% (Figure 2). On the other hand, the treated wood with both EO and OLE showed weak activity against Fusarium solani (Figure 3); however, P. halepensis OLE at 3\% showed inhibition against its growth. Figure 4 shows that, in the control treatment, the fungal mycelia of Rhizoctonia solani covered and grew over the wood samples after the incubation period. Meanwhile, either the growth did not completely reach the direction of the treated wood, or no growth was found at all.

\section{F. oxysporum with control \\ wood}
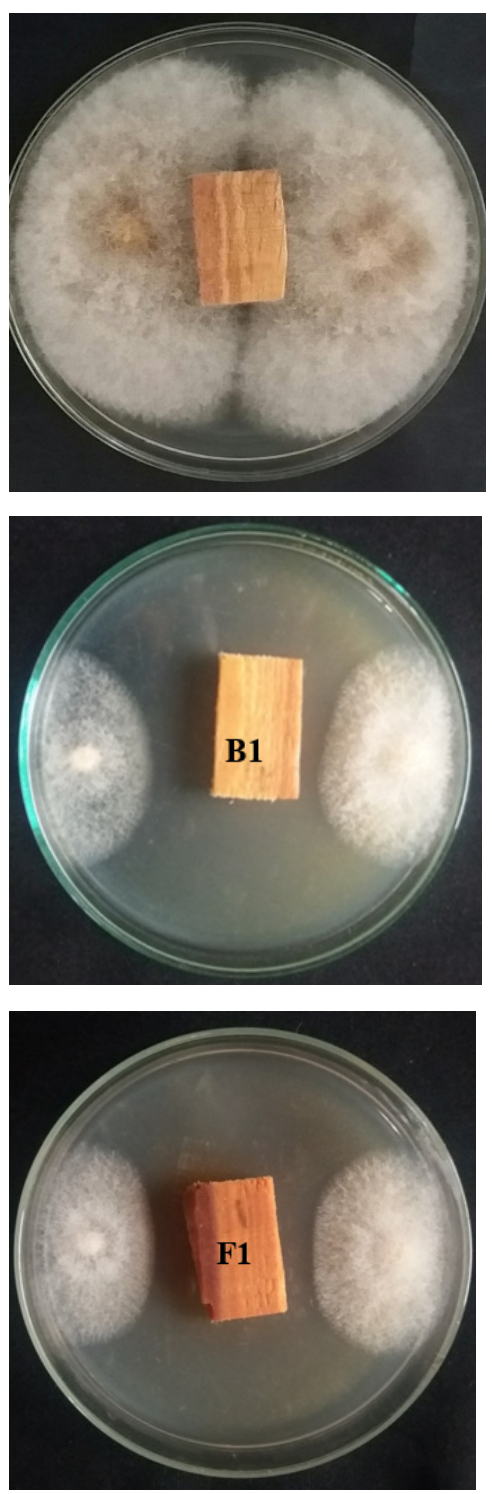

F. oxysporum growth
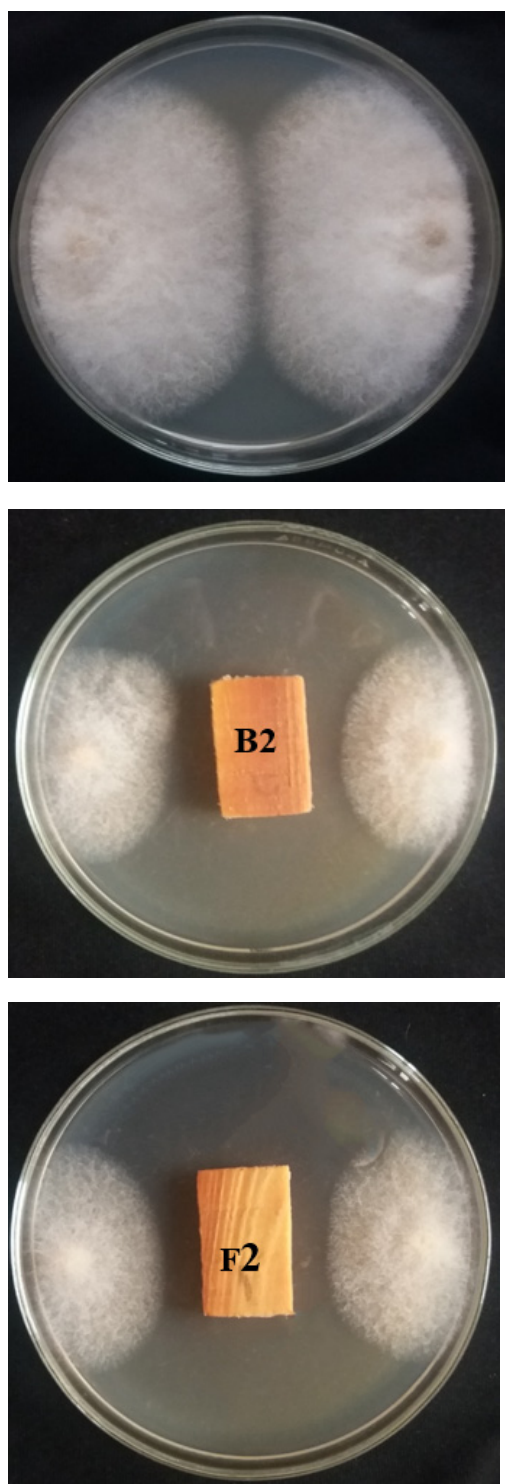

F. oxysporum
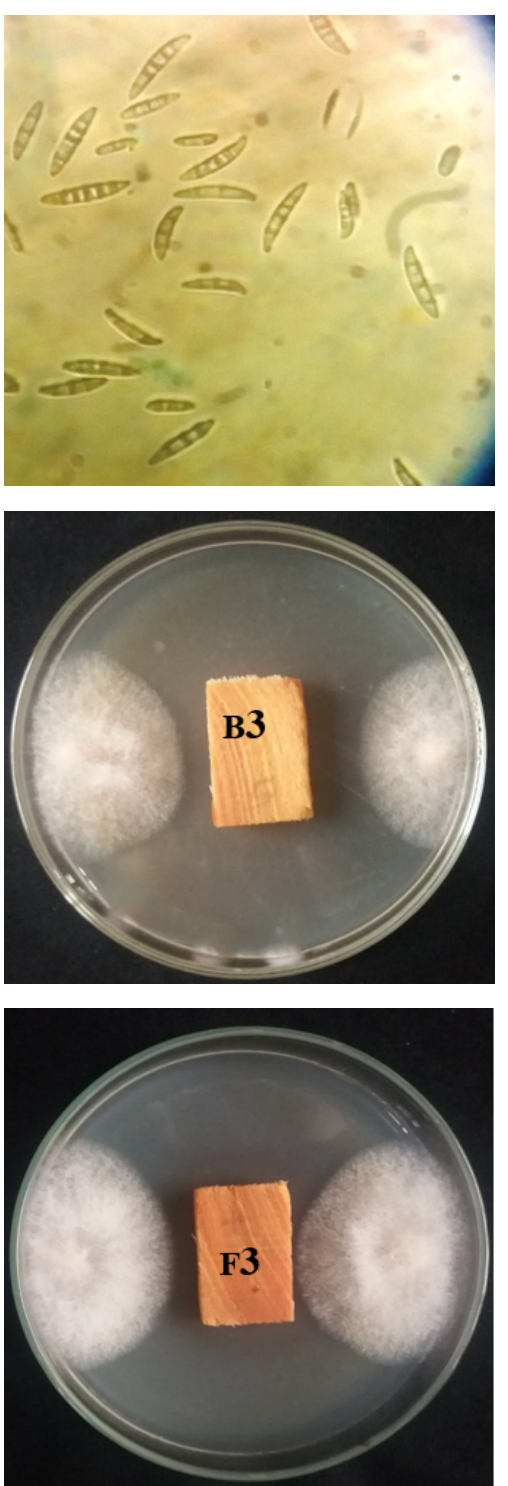

Figure 2. Antifungal bioassay of wood treated with (B) P. halepensis OLE and (F) S. terebinthifolius EO against the growth of F. oxysporum. B1: 3\%; B2: 2\%; B3: 1\%; F1: 3\%; F2: 2\%; F3: $1 \%$. 
F. solani with control wood
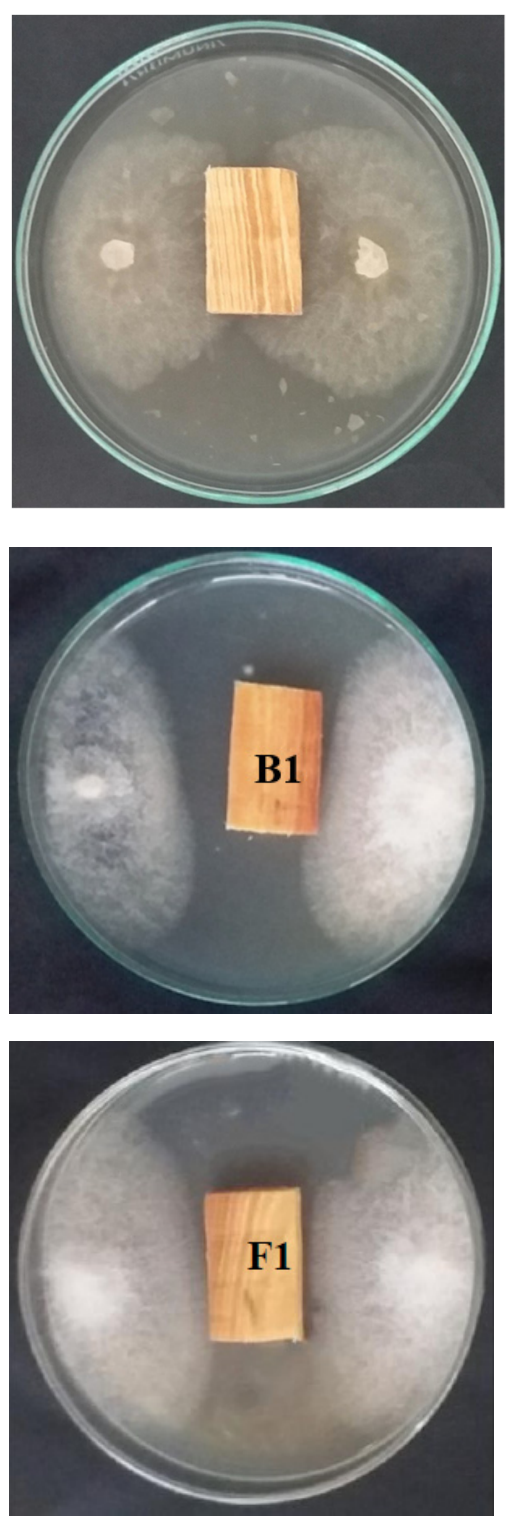

F. solani
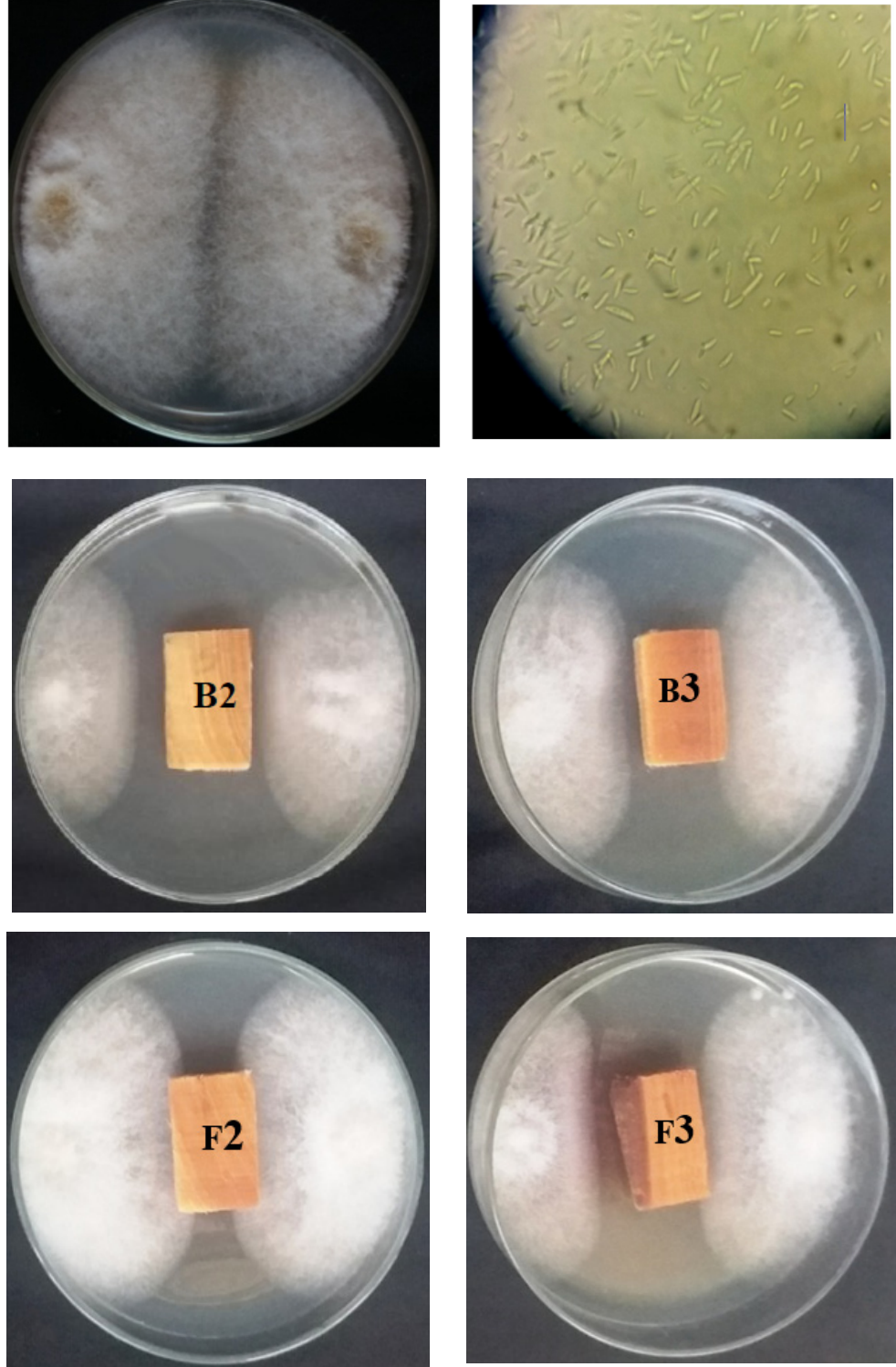

Figure 3. Antifungal bioassay of wood treated with (B) P. halepensis OLE and (F) S. terebinthifolius EO against the growth of F. solani. B1: 3\%; B2: 2\%; B3: 1\%; F1: 3\%; F2: 2\%; F3: 1\%. 
R. solani with wood
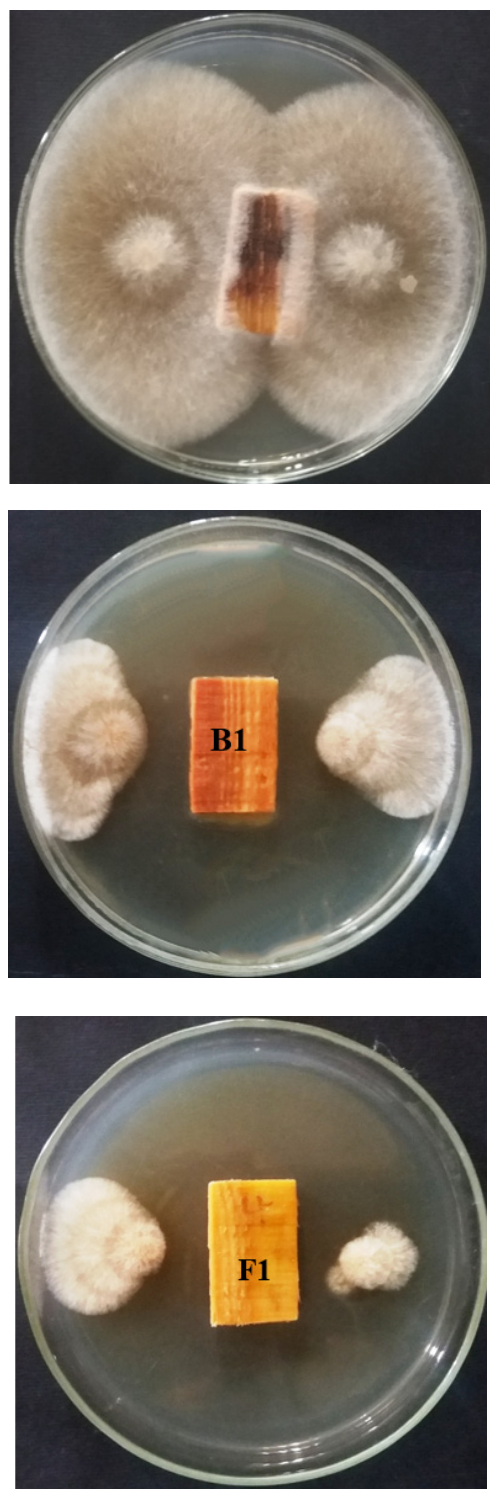

Control of R. solani
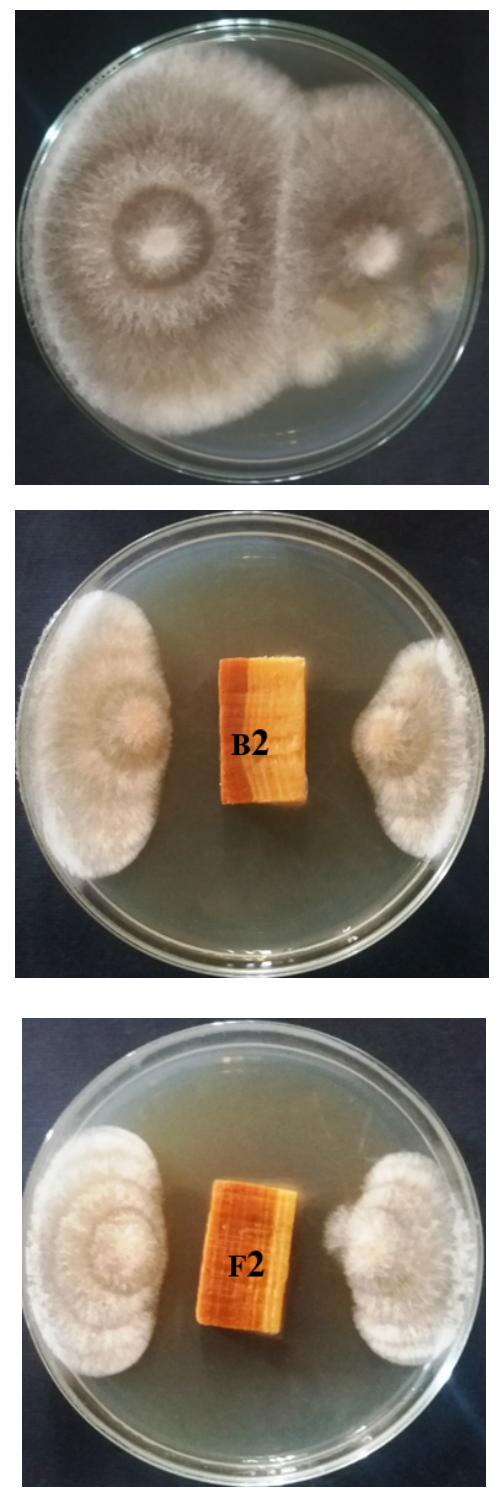

R. solani
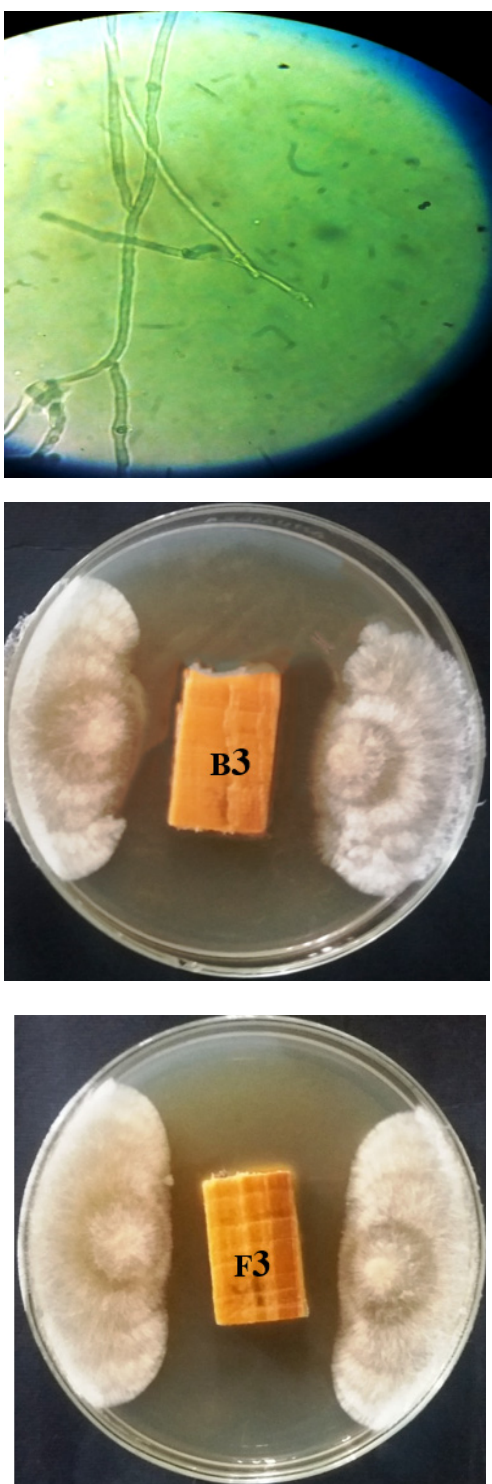

Figure 4. Antifungal bioassay of wood treated with (B) P. halepensis OLE and (F) S. terebinthifolius EO against the growth of $R$. solani. B1: 3\%; B2: 2\%; B3: 1\%; F1: 3\%; F2: 2\%; F3: $1 \%$.

Furthermore, as shown in Figure 4, the fungal growth of R. solani was found in the opposite direction of the treated wood with the P. halepensis OLE and Schinus terebinthifolius EO.

\subsection{Antifungal Activity of the Oils}

Statistically, there was a significance effect of EO and OLE in terms of antifungal activity against B. oryzae, F. oxysporum, F. solani, and R. solani (Figure 5a), where P. halepensis OLE had the highest effect against the growth of F. oxysporum and F. solani. Meanwhile, S. terebinthifolius EO was found to have good activity against B. oryzae and $R$. solani. Furthermore, when increasing the EO or OLE concentration from $0 \%$ (control) to $3 \%$, the inhibition percentage of fungal growth (IPFG) was increased (Figure 5b). 

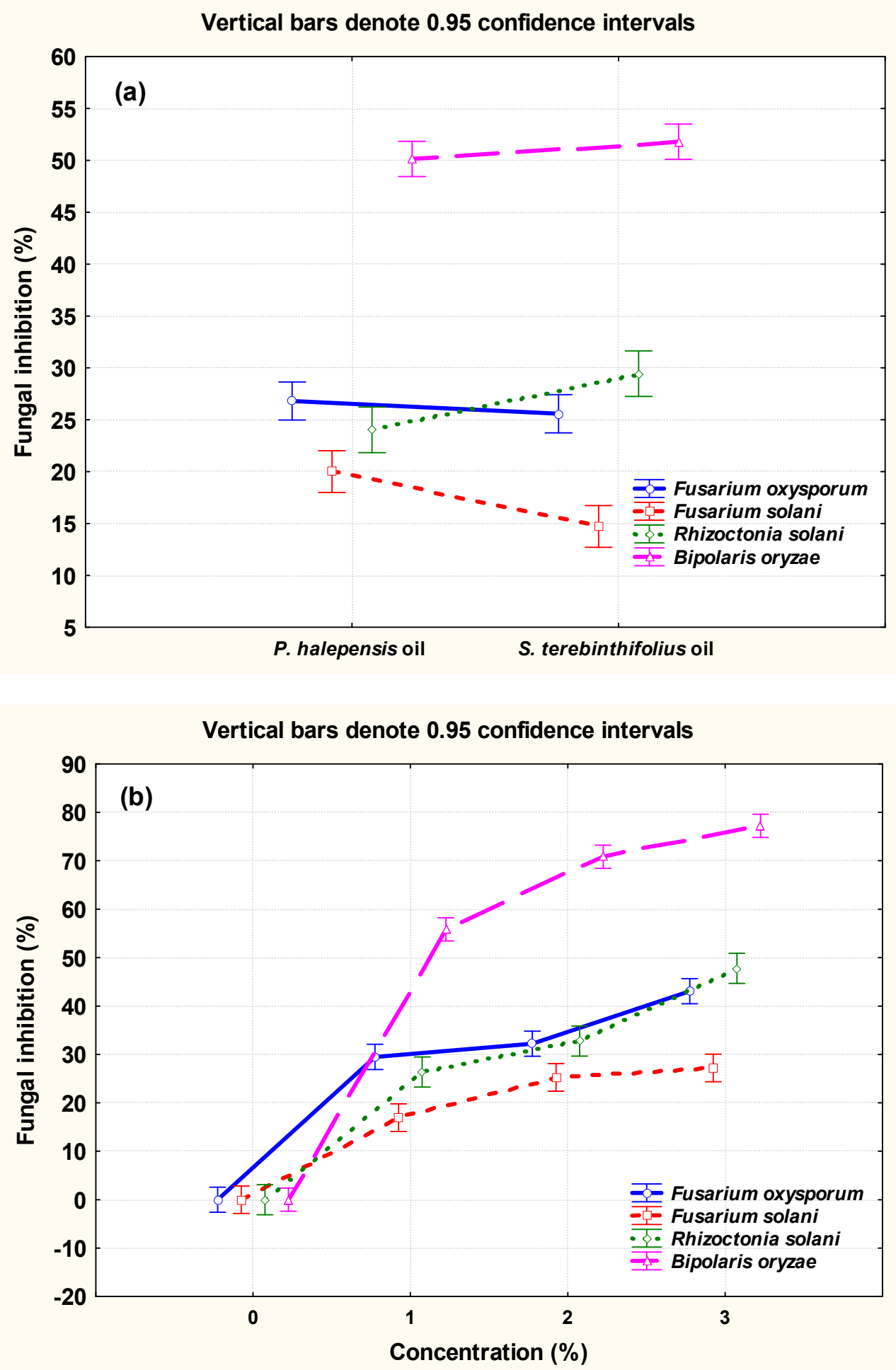

Figure 5. Overall bioactivity of wood treated with P. halepensis OLE and S. terebinthifolius EO; (a) EO and OLE source and (b) EO and OLE concentration against the fungal linear growth of B. oryzae, $F$. oxysporum, F. solani, and R. solani.

For the effect of EO/OLE-treated wood as affected by the interaction between the EO/OLE type and their concentrations (Table 1 ), the highest activity against $B$. oryzae growth was found for P. halepensis OLE applied at a concentration of $3 \%$, followed by S. terebinthifolius EO at $3 \%$ and $2 \%$, with IPFG values of $80 \%, 74.44 \%$, and $71.66 \%$, respectively. S. terebinthifolius EO and P. halepensis OLE at a 
concentration of $3 \%$ observed the highest IPFG, with values of $45.55 \%$ and $40.55 \%$, respectively, against F. oxysporum growth.

Wood treated with $P$. halepensis OLE at the $3 \%$ and $2 \%$ concentration levels showed significant activity against the growth of F. solani, with IPFG values of $30.55 \%$ and $29.44 \%$, respectively. Also, S. terebinthifolius EO (2\%) and P. halepensis OLE (1\%) showed IPFG values of $21.11 \%$ and $20 \%$, respectively. The highest activity against the growth of $R$. solani was observed for wood treated with S. terebinthifolius EO and P. halepensis OLE at 3\%, with IPFG values of 54.44\% and $41.11 \%$, respectively. However, S. terebinthifolius EO and P. halepensis OLE at $2 \%$ showed IPFG values of 35\% and 30.55\%, respectively, against $R$. solani.

Table 1. Inhibition percentages of fungal growth (\%) as affected by wood treated with P. halepensis OLE and S. terebinthifolius EO.

\begin{tabular}{cccccc}
\hline \multirow{2}{*}{ Oil/Extract Type } & Concentration (\%) & \multicolumn{4}{c}{ Fungal Inhibition (\%) } \\
\cline { 3 - 6 } & & B. oryzae & F. oxysporum & F. solani & R. solani \\
\hline \multirow{2}{*}{ P. halepensis OLE } & 1 & 0.00 & 0.00 & 0.00 & 0.00 \\
& 2 & $50.55 \pm 4.92$ & $31.11 \pm 4.05$ & $20 \pm 9.07$ & $24.44 \pm 4.05$ \\
& 3 & $70 \pm 5.28$ & $35.55 \pm 6.60$ & $29.44 \pm 4.20$ & $30.55 \pm 7.34$ \\
S. terebinthifolius & $0($ control) & $0.00 \pm 1.81$ & $40.55 \pm 4.58$ & $30.55 \pm 2.12$ & $41.11 \pm 2.86$ \\
\hline EO & 1 & $61.11 \pm 2.86$ & $23.44 \pm 2.93$ & $13.88 \pm 2.12$ & $28.33 \pm 3.79$ \\
& 2 & $71.66 \pm 3.79$ & $33.33 \pm 1.81$ & $21.11 \pm 2.86$ & $35 \pm 2.12$ \\
\hline -value & 3 & $74.44 \pm 2.86$ & $45.55 \pm 2.86$ & $23.88 \pm 2.12$ & $54.44 \pm 6.91$ \\
\hline
\end{tabular}

\subsection{Chemical Composition of Branches from S. terebinthifolius Eessntial Oil and P. halepensis Oily} Liquid Extract

The chemical composition of the EO identified in S. terebinthifolius branch is shown in Table 2 . The main compounds were terpinen-4-ol $(18.25 \%)$, cis- $\beta$-terpineol $(15.60 \%), \gamma$-terpinene $(12.46 \%)$, sabinene $(9.83 \%), \alpha$-terpinene $(8.56 \%)$, 4-thujanol (6.71\%), (-)- $\alpha$-terpineol (4.34\%), o-cymene $(4.05 \%)$, D-limonene $(2.79 \%), \alpha$-phellandrene $(2.46 \%)$, and $\beta$-caryophyllene $(2.34 \%)$. The chemical compounds of $P$. halepensis branch OLE are presented in Table 3 . The main compounds were 2-undecenal (22.25\%), 4-hydroxy-10-methyl-3,4,7,8,9,10-hexahydro-2H-oxecin-2-one (8.43\%), (Z)-2-decenal (6.88\%), nonanal (5.85\%), (2E)-2-decenal (4.65\%), (E,E)-2,4-decadienal (4.41\%), arachidonic acid methyl ester (4.36\%), 2-(7-heptadecynyloxy)tetrahydro-2H-pyran (4.22\%), 1-nonadecene (3.50\%), 12,15-octadecadiynoic acid, methyl ester (3.1\%), Z-(13,14-epoxy)tetradec-11-en-1-ol acetate (3.04\%), 7-methyl-Z-tetradecen-1-ol acetate (3.01\%), (Z)-2-tridecenal (2.9\%), O-benzylserine (2.22\%), methyl octadeca-13,16-diynoate (2.21\%), myristyl chloride (1.97\%), (Z)-oleic acid (1.48\%), n-caprylaldehyde $(1.31 \%)$, and 1-heptatriacotanol (1.15\%). 
Table 2. Phytochemicals of essential oil from $S$. terebinthifolius branches by gas chromatography-mass spectrometry (GC-MS).

\begin{tabular}{|c|c|c|c|c|}
\hline Compound & Chemical Classification & $\begin{array}{l}\text { Percentage in the } \\
\text { Oil (\%) }\end{array}$ & $\mathrm{SI}^{1}$ & $\mathrm{RSI}^{2}$ \\
\hline$\alpha$-Thujene & Monoterpene & 0.94 & 935 & 954 \\
\hline$\alpha$-Pinene & Monoterpene & 1.21 & 960 & 962 \\
\hline Sabinene & Monoterpene & 9.83 & 961 & 968 \\
\hline$\beta$-Pinene & Monoterpene & 0.32 & 942 & 952 \\
\hline Myrcene & Monoterpene & 1.88 & 943 & 945 \\
\hline$\alpha$-Terpinene & Monoterpene & 8.56 & 939 & 944 \\
\hline D-Limonene & Monoterpene & 2.79 & 926 & 929 \\
\hline$\alpha$-Phellandrene & Monoterpene & 2.46 & 918 & 921 \\
\hline$o$-Cymene & Monoterpene & 4.05 & 926 & 937 \\
\hline$\gamma$-Terpinene & Monoterpene & 12.46 & 936 & 941 \\
\hline Artemisia ketone & Monoterpene & 0.33 & 774 & 974 \\
\hline 4-Thujanol & Monoterpene & 6.71 & 888 & 890 \\
\hline Linalool & Monoterpene & 0.74 & 922 & 934 \\
\hline cis- $\beta$-Terpineol & Monoterpene & 15.60 & 928 & 937 \\
\hline para-Menth-3-en-1-ol & Monoterpene & 1.85 & 888 & 893 \\
\hline cis-para-2-menthen-1-ol & Monoterpene & 0.64 & 903 & 918 \\
\hline Camphor & Monoterpene & 0.23 & 765 & 820 \\
\hline Terpinen-4-ol & Monoterpene & 18.25 & 931 & 937 \\
\hline (Z)-Piperitol & Monoterpene & 0.28 & 873 & 927 \\
\hline (-)- $\alpha$-Terpineol & Monoterpene & 4.34 & 941 & 945 \\
\hline trans-Piperitol & Monoterpene & 0.14 & 866 & 925 \\
\hline Linalyl acetate & Monoterpene & 1.63 & 899 & 921 \\
\hline 2,2-Dimethyl-3-vinyl-bicyclo[2.2.1]heptane & Hydrocarbons & 0.26 & 748 & 807 \\
\hline Thymol & Monoterpene & 1.19 & 866 & 903 \\
\hline$\beta$-Caryophyllene & Sesquiterpene & 2.34 & 922 & 941 \\
\hline$\gamma$-Elemene & Sesquiterpene & 0.95 & 849 & 885 \\
\hline
\end{tabular}

${ }^{1}$ SI: Standard index; ${ }^{2}$ RSI: Reverse standard index.

Table 3. Phytochemicals of oily liquid extract from P. halepensis branches by GC/MS.

\begin{tabular}{ccccc}
\hline Compound & Chemical Classification & $\begin{array}{c}\text { Percentage in the } \\
\text { Extract (\%) }\end{array}$ & SI $^{\mathbf{1}}$ & RSI $^{\mathbf{2}}$ \\
\hline 2,7-dimethyl-1-Octanol & Terpene hydrocarbon & 0.70 & 706 & 783 \\
2,6-Dimethyloctane-1,8-diol & Terpene hydrocarbon & 0.25 & 675 & 675 \\
(E)-2-Decen-1-ol & Unsaturated aldehydes & 0.57 & 705 & 775 \\
(2-Hexylcyclopropyl)acetic acid & Hydrocarbons & 0.29 & 718 & 758 \\
1-Dodecene & Unsaturated aldehydes & 0.47 & 742 & 742 \\
n-Caprylaldehyde & Alkyl aldehyde & 1.31 & 803 & 934 \\
Isopinocarveol & Pinane monoterpene & 0.97 & 708 & 748 \\
(E)-9-Tetradecen-1-ol acetate & Unsaturated aldehydes & 0.45 & 751 & 783 \\
trans-2-Decenal & Unsaturated aldehydes & 0.40 & 884 & 921 \\
(Z)-2-Decenal & Unsaturated aldehydes & 6.88 & 901 & 932 \\
(2E)-2-Decenal & Unsaturated aldehydes & 4.65 & 884 & 919 \\
Nonanal & Fatty aldehydes & 5.85 & 870 & 887 \\
Oxacyclotetradecan-2-one & Ketone & 0.32 & 751 & 752 \\
Methyl octadeca-13,16-diynoate & Fatty acid methyl ester & 2.21 & 742 & 750 \\
1-Tetradecanol & Saturated fatty alcohol & 0.32 & 767 & 768 \\
(Z)-2-Tridecenal & Unsaturated aldehydes & 2.9 & 771 & 814 \\
Undecanoic acid, hydroxy-, lactone & Fatty acid & 0.19 & 740 & 757 \\
1,2-15,16-Diepoxyhexadecane & Alkane hydrocarbon & 0.74 & 780 & 782 \\
5-heptyldihydro-2(3H)-furanone & gamma butyrolactones & 0.32 & 734 & 745 \\
(E,E)-2,4-Decadienal & Unsaturated aldehydes & 4.41 & 838 & 870 \\
\hline
\end{tabular}


Table 3. Cont.

\begin{tabular}{|c|c|c|c|c|}
\hline Compound & Chemical Classification & $\begin{array}{l}\text { Percentage in the } \\
\text { Extract }(\%)\end{array}$ & $\mathrm{SI}^{1}$ & RSI $^{2}$ \\
\hline (Z)-Oleic acid & Fatty acid & 1.48 & 770 & 770 \\
\hline 2-Undecenal & Unsaturated aldehydes & 22.25 & 890 & 903 \\
\hline Olealdehyde & Aldehydes & 0.69 & 727 & 792 \\
\hline Arachidonic acid methyl ester & Fatty acid methyl ester & 4.36 & 753 & 760 \\
\hline Myristyl chloride & Fatty acid & 1.97 & 735 & 755 \\
\hline Z,Z,Z-1,4,6,9-Nonadecatetraene & Unsaturated aldehydes & 0.68 & 741 & 741 \\
\hline $\begin{array}{l}\text { 4-Hydroxy-10-methyl-3,4,7,8,9,10- } \\
\text { hexahydro-2H-oxecin-2-one }\end{array}$ & Ketone & 8.43 & 844 & 890 \\
\hline 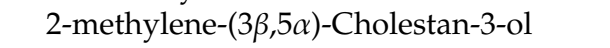 & Steroids & 0.87 & 772 & 782 \\
\hline (Z)-7-Hexadecenal & Unsaturated aldehydes & 0.46 & 747 & 890 \\
\hline Vitamin A aldehyde (Retinal) & Retinoids & 0.21 & 701 & 771 \\
\hline 9-Hexadecenoic acid & Fatty acid & 1.08 & 788 & 789 \\
\hline 1-Heptatriacotanol & Fatty alcohol & 1.15 & 728 & 730 \\
\hline O-Benzylserine & Amino acid & 2.22 & 766 & 776 \\
\hline 12,15-Octadecadiynoic acid, methyl ester & Fatty acid & 3.1 & 743 & 753 \\
\hline 2-(7-heptadecynyloxy)tetrahydro-2H-Pyran & Hydrocarbons & 4.22 & 697 & 697 \\
\hline 1-Nonadecene & Hydrocarbons & 3.50 & 724 & 757 \\
\hline $\begin{array}{l}\text { Z-(13,14-Epoxy)tetradec-11-en-1-ol } \\
\text { acetate }\end{array}$ & Hydrocarbons & 3.04 & 785 & 794 \\
\hline 7-Methyl-Z-tetradecen-1-ol acetate & Hydrocarbons & 3.01 & 747 & 762 \\
\hline
\end{tabular}

${ }^{1}$ SI: Standard index; ${ }^{2}$ RSI: Reverse standard index.

\section{Discussion}

Pinus halepensis OLE and Schinus terebinthifolius EO showed the presence of several bioactive compounds, as identified by Gas Chromatography-Mass Spectrometry (GC/MS). 2-undecenal, as well as other compounds such as 4-hydroxy-10-methyl-3,4,7,8,9,10-hexahydro-2H-oxecin-2-one, (Z)-2-decenal, nonanal, (2E)-2-decenal, $(E, E)$-2,4-decadienal, arachidonic acid methyl ester, and 2-(7-heptadecynyloxy)tetrahydro-2H-pyran, were found in the OLE of P. halepensis.

Several cited chemical compositions of $P$. halepensis have been published regarding terpenes, fatty acids, aldehydes, and cyclic phenolic compounds [59-61]. The lipophilic extractives (resin acids, terpenes, fatty acids, glycerides, steryl esters, sterols) were extracted using n-hexane then the hydrophilic ones (stilbenes, flavanols, monosaccharides, sugar alcohols) with acetone/water from sapwood and heartwood of P. halepensis stem [62]. Additionally, lipophilic and hydrophilic extractives were analyzed with GC-MS that were more abundant in heartwood than in sapwood of P. halepensis [63]. Seed oil of $P$. halepensis extracted with hexane was rich in fatty acid composition with linoleic and oleic acids accounting for more than $76 \%$ [64].

Terpinen-4-ol, cis- $\beta$-terpineol, $\gamma$-terpinene, sabinene, $\alpha$-terpinene, and 4 -thujanol were identified as the main compounds in S. terebinthifolius branch EO. The EO from S. terebinthifolius showed the presence of several compounds related to monoterpenes, sesquiterpene, and some other organic compounds [65-71]. Another study showed that the most abundant component of S. terebinthifolius EO was limonene [6]; also, $\alpha$-phellandrene, $\beta$-phellandrene, $\alpha$-pinene, and limonene were reported in the EO of $S$. terebinthifolius [69,72].

S. terebinthifolius EO compounds such as $\alpha$ - $\beta$-pinene, $\alpha$-funebrene, $Z$-salvene, sabinene, and limonene [73] were isolated from fruits, while the compounds $\beta$-Longipinene, bicyclogermacrene, germacrene $\mathrm{D}$, and $\beta$-pinene were found in leaves [74]. Although, mixed monoterpenes and sesquiterpenes were reported in unripe fruits; namely, $\alpha$-cadinol, $\delta$-cadinene, elemole, $\Delta^{3}$-carene, germacrene D-4-ol, $\beta$-phellandrene, epi- $\alpha$-cadinol, and germacrene D [67]. On the other hand, the terpenes limonene, sabinene, $\Delta^{3}$-carene, and $p$-cymene were detected as main components of $S$. terebinthifolius ripe fruit EO [27]. 
In the present study, both oils were observed to have potential antimicrobial activity in terms of microbial inhibition when treating wood. The monoterpenic or sesquiterpenic hydrocarbons and their oxygenated derivatives are considered as potential antimicrobial agents by many studies. Thus, these results agree with other previous works $[9,18,21,26,75,76]$.

Recently, schinol and a new biphenyl compound (4'-ethyl-4-methyl-2,2',6,6' $6^{\prime}$-tetrahydroxyl(1.1'biphenyl)-4, $4^{\prime}$-dicarboxylate), isolated from hexane and dichloromethane fractions obtained from leaves and stems, showed marked antifungal activity against P. brasiliensis [34]. Santos et al. [77] found that EOs from S. terebinthifolius and S. molle could be a possible alternative to control diseases caused by phytopathogenic fungi that affect agricultural production. The EOs from S. terebinthifolius showed a pronounced fungicide effect against Botrytis ssp isolated from "gerberas" and roses [73]. The antifungal activity may be attributed to the presence of the said chemical components in the EO; for instance, $\mathrm{O}$-cymene and limonene have been shown to have strong antifungal properties [78]. Nevertheless, the mechanism of antifungal activity of this EO is still unknown. However, a recent study on the induced damage to the cell membrane structure of yeast and isolated mitochondria suggests that phytoconstituents from the EO of S. terebinthifolius are likely to disrupt the permeability barrier of the cell membranes and thereby inhibit respiration $[79,80]$. Furthermore, it has been suggested that the differences in susceptibility of tested organisms to monoterpenes and the differences in the efficacy of different monoterpenes may possibly be explained by the variation in the rate of monoterpene penetration and characteristic membrane structure [80].

Several authors who have studied the antimicrobial activity of Pinaceae family [81-83] report that monoterpenes possess a high antifungal activity. The absence of monoterpenes in our EO can explain the absence of a very high activity of Aleppo pine EO, but aldehydes are often found as constituents of plant products [84] and may play an important role in the observed antimicrobial activity of plant aldehyde-containing material [85]. Their action, very likely due to an alteration in the function of membrane-associated proteins, seems to be exerted mainly at the cell surface. However, the capability to penetrate the outer layer of cells can help to explain the antimicrobial activity of some aldehydes, especially against Gram-negative bacteria $[86,87]$. On the other hand, the antifungal activity of our EO may due to the presence of $n$-caprylaldehyde (hexanal) which is commercially used to produce fruity flavors and to prevent fruit spoilage. Meanwhile, another study confirmed that the saturated aldehydes hexanal, nonanal, and (E)-2-octenal showed almost no antimicrobial activity against some clinical bacteria [88], while the same study proved that the complex of long chain aldehydes-which highly presented in our EO-has very good antimicrobial activity, as they stated that $\alpha, \beta$-unsaturated aldehydes ((E)-2-eptenal, $(E)$-2-nonenal, $(E)$-2-decenal, and $(E, E)$-2,4-decadienal) were tested together $($ ratio $=1: 1: 1: 1)$ against ATCC bacterial isolates and clinically isolated microbial strains, and a strong synergic effect was observed [88]. Moreover, the effectiveness of the aldehydes seems to depend not only on the presence of the $\alpha, \beta$-double bond, but also on the chain length from the enal group and on the microorganism tested. Finally these oil $\alpha, \beta$-unsaturated aldehydes might be good alternatives to other highly toxic disinfectants, such as glutaraldehyde [89]. In another study [18], the P. halepensis EO was shown to possess antifungal activity against A. flavus, A. niger, F. oxysporum, and R. stolonifera, and thus can be used as a natural treatment for fungal infections, as well as a natural preservative in food.

The treated wood of Acacia saligna at the concentration of $5 \%$ with the methanolic extracts of Morus alba heartwood, Cupressus sempervirens wood, and Maclura pomifera bark showed no fungal growth of T. harzianum on the surface of the wood [52]. An inhibition zone was found against T. harzianum for A. saligna wood treated with the methanolic extract of $C$. sempervirens wood at concentrations of $5 \%, 10 \%$, and $20 \%$ [52]. Wood samples of P. sylvestris, F. sylvatica, and P. rigida treated with the EOs or extracts from E. camaldulensis leaves or P. rigida wood had a potential effect against the growth of some phytopathogenic fungi $[54,56]$.

Acer saccharum bark acetone extract, in combination with citric acid, applied to Leucaena leucocephala wood showed some activities against T. viride, F. subglutinans, and A. niger [4]. No growth of A. flavus and C. gloeosporioides was observed for sheets of Papyrus (Cyperus papyrus L.) strips pre-treated with 
P. rigida and E. camaldulensis or Salix babylonica extracts [90]. Melia azedarach wood samples treated with $A$. saligna flowers water extract showed activity and growth inhibition against F. culmorum, $R$. solani, and P. chrysogenum [8], while the same treated with the methanol extract of Musa paradisiaca peels showed potential antifungal activity against F. culmorum and R. solani [7]. Additionally, the same wood treated with oils extracted with $n$-hexane from E. camaldulensis and Vitex agnus-castus showed promising antifungal activities against F. culmorum, R. solani, and P. chrysogenum [3].

Among the chemical components of the oils, there are synergistic or antagonistic interaction effects. The mode of action of EOs has been investigated by many authors, who suggested that antimicrobial activity is produced by interactions provoked by terpenes in the enzymatic systems related with energy production and in the synthesis of structural components of the microbial cells [91]. Other reports have suggested that the components of the EOs cross the cell membrane, interacting with the enzymes and proteins of the membrane such as the $\mathrm{H}^{+}$-ATPase pumping membrane, thus producing a flux of protons toward the cell exterior, which induces changes in the cells and, ultimately, their death [92]. Furthermore, several works [93-96] have explained how the antimicrobial ability of terpenes stop the functions of cell membranes, not only the permeability, how they might penetrate the membrane to the cell interior organs and interact critically with intracellular sites. Moreover, Daferera et al. [97] reported that the antifungal activity of EOs may be due to formation of hydrogen bonds between the hydroxyl group of oil phenols and the active sites of the target enzymes.

\section{Conclusions}

The antifungal activity of the wood of Pinus roxburghii treated with $P$. halepensis branch $n$-hexane oily liquid extract and S. terebinthifolius branch essential oil was tested against B. oryzae, F. oxysporum, F. solani, and $R$. solani. Both the extracted essential oil and oily liquid extract inhibited F. oxysporum isolate growth with a percentage of ca. $40 \%$ at a concentration of $3 \%$, and showed good bioactivity against the growth of B. oryzae, F. oxysporum, and R. solani. These activities could be related to monoterpenoids, the most abundant compounds identified in the extracts. Therefore, both natural extracted materials could be considered as a wood-biofungicide agent and for their possible use on a larger scale.

Author Contributions: A.A.M., S.I.B., H.M.A., M.E.-H., M.Z.M.S., and N.A.A. designed the experiments, conducted the laboratory analyses, wrote parts of the manuscript, and interpreted the results; all coauthors contributed to writing and revising the article. All authors have read and agreed to the published version of the manuscript.

Funding: This research was funded by Researchers Supporting Project number (RSP-2019/123) King Saud University, Riyadh, Saudi Arabia.

Acknowledgments: Researchers Supporting Project number (RSP-2019/123) King Saud University, Riyadh, Saudi Arabia.

Conflicts of Interest: The authors declare no conflicts of interest.

\section{References}

1. Mansour, M.M.A.; EL-Hefny, M.; Salem, M.Z.M.; Ali, H.M. The Biofungicide Activity of Some Plant Essential Oils for the Cleaner Production of Model Linen Fibers Similar to Those Used in Ancient Egyptian Mummification. Processes 2020, 8, 79. [CrossRef]

2. Salem, M.Z.M.; Hamed, S.A.M.; Mansour, M.M.A. Assessment of efficacy and effectiveness of some extracted bio-chemicals as bio-fungicides on Wood. Drv. Ind. 2019, 70, 337-350. [CrossRef]

3. Salem, M.Z.M.; Behiry, S.I.; EL-Hefny, M. Inhibition of Fusarium culmorum, Penicillium chrysogenum and Rhizoctonia solani by $n$-hexane extracts of three plant species as a wood-treated oil fungicide. J. Appl. Microbiol. 2019, 126, 1683-1699. [CrossRef]

4. Salem, M.Z.M.; Mansour, M.M.A.; Elansary, H.O. Evaluation of the effect of inner and outer bark extracts of Sugar Maple (Acer saccharum var. saccharum) in combination with citric acid against the growth of three common molds. J. Wood Chem. Technol. 2019, 39, 136-147. [CrossRef] 
5. Mohamed, W.A.; Mansour, M.M.A.; Salem, M.Z.M. Lemna gibba and Eichhornia crassipes extracts: Clean alternatives for deacidification, antioxidation and fungicidal treatment of historical paper. J. Clean. Prod. 2019, 219, 846-855. [CrossRef]

6. EL-Hefny, M.; Abo Elgat, W.A.A.; Al-Huqail, A.A.; Ali, H.M. Essential and recovery oils from Matricaria chamomilla flowers as environmentally friendly fungicides against four fungi isolated from cultural heritage objects. Processes 2019, 7, 809. [CrossRef]

7. Behiry, S.I.; Okla, M.K.; Alamri, S.A.; EL-Hefny, M.; Salem, M.Z.M.; Alaraidh, I.A.; Ali, H.M.; Al-Ghtani, S.M.; Monroy, J.C.; Salem, A.Z.M. Antifungal and antibacterial activities of Musa paradisiaca L. peel extract: HPLC analysis of phenolic and flavonoid contents. Processes 2019, 7, 215. [CrossRef]

8. Al-Huqail, A.A.; Behiry, S.I.; Salem, M.Z.M.; Ali,H.M.; Siddiqui, M.H.; Salem, A.Z.M. Antifungal, antibacterial, and antioxidant activities of Acacia saligna (Labill.) H. L. Wendl. flower extract: HPLC analysis of phenolic and flavonoid compounds. Molecules 2019, 24, 700. [CrossRef] [PubMed]

9. Ashmawy, N.A.; Al Farraj, D.A.; Salem, M.Z.M.; Elshikh, M.S.; Al-Kufaidy, R.; Alshammari, M.k.; Salem, A.Z.M. Potential impacts of Pinus halepensis Miller trees as a source of phytochemical compounds: Antibacterial activity of the cones essential oil and n-butanol extract. Agrofor. Syst. 2018. [CrossRef]

10. Shabana, Y.M.; Abdel-Fattah, G.M.; Ismail, A.E.; Rashad, Y.M. Control of brown spot pathogen of rice (Bipolaris oryzae) using some phenolic antioxidants. Braz. J. Microbiol. 2008, 39, 438-444. [CrossRef]

11. Olivain, C.; Trouvelot, S.; Binet, M.; Cordier, C.; Pugin, A.; Alabouvette, C. Colonization of flax roots and early physiological responses of flax cells inoculated with pathogenic and non-pathogenic strains of Fusarium oxysporum. Appl. Environ. Microb. 2003, 69, 5453-5462. [CrossRef] [PubMed]

12. Coleman, J.J. The Fusarium solani species complex: Ubiquitous pathogens of agricultural importance. Mol. Plant Pathol. 2016, 17, 146-158. [CrossRef] [PubMed]

13. Homa, M.; Galgóczy, L.; Manikandan, P.; Narendran, V.; Sinka, R.; Csernetics, Á.; Papp, T. South Indian Isolates of the Fusarium solani Species Complex from Clinical and Environmental Samples: Identification, Antifungal Susceptibilities, and Virulence. Front. Microbiol. 2018, 9. [CrossRef] [PubMed]

14. Dean, R.; Van Kan, J.A.; Pretorius, Z.A.; Hammond-Kosack, K.E.; Di Pietro, A.; Spanu, P.D.; Rudd, J.J.; Dickman, M.; Kahmann, R.; Ellis, J. The top 10 fungal pathogens in molecular plant pathology. Mol. Plant Pathol. 2012, 13, 414-430. [CrossRef]

15. Villarino, M.; de la Lastra, E.; Basallote, M.J.; Capote, N.; Inmaculada, L.; Melgarejo, P.; De Cal, A. Characterization of Fusarium solani populations associated with Spanish strawberry crops. Plant Dis. 2019. [CrossRef]

16. El-Shafey, R.A.S.; Elamawi, R.M.; Saleh, M.M.; Tahoon, A.M.; Emeran, A.A. Morphological, pathological and molecular characterisation of rice sheath blight disease causal organism Rhizoctonia solani AG-1 IA in Egypt. Arch. Phytopathol. Plant Prot. 2019. [CrossRef]

17. Tumen, I.; Hafizoglu, H.; Kilic, A.; Dönmez, I.E.; Sivrikaya, H.; Reunanen, M. Yields and constituents of essential oil from cones of Pinaceae spp. natively grown in Turkey. Molecules 2010, 15, 5797-5806. [CrossRef]

18. Abi-Ayad, M.; Abi-Ayad, F.Z.; Lazzouni, H.A.; Rebiahi, S.A.; Ziani-Cherif, C.; Bessiere, J.M. Chemical composition and antifungal activity of Aleppo pine essential oil. J. Med. Plant Res. 2010, 5, 5433-5436.

19. Abi-Ayad, M.; Abi-Ayad, F.Z.; Lazzouni, H.A.; Rebiahi, S.A. Antibacterial activity of Pinus halepensis essential oil from Algeria (Tlemcen). J. Nat. Prod. Plant Resour. 2010, 1, 33-36.

20. Nam, A.M.; Tomi, F.; Gibernau, M.N.; Cordier, C.; Pugin, A.; Alabouvette, C. Composition and chemical variability of the needle oil from Pinus halepensis growing in Corsica. Chem. Biodivers. 2016, 13, 380-386. [CrossRef]

21. Mohareb, A.S.O.; Kherallah, I.E.A.; Badawy, M.E.I.; Salem, M.Z.M.; Hameda, A.Y. Chemical composition and activity of bark and leaf extracts of Pinus halepensis and Olea europaea grown in AL-Jabel AL-Akhdar region, Libya against some plant phytopathogens. J. Appl. Biotechnol. Bioeng. 2017, 3, 331-342.

22. Dob, T.; Berramdane, T.; Chelghoum, C. Essential oil composition of Pinus halepensis Mill. from three different regions of Algeria. J. Essent. Oil Res. 2007, 19, 40-43. [CrossRef]

23. Djerrad, Z.; Djouahri, A.; Kadik, L. Variability of Pinus halepensis Mill. Essential oils and their antioxidant activities depending on the stage of growth during vegetative cycle. Chem. Biodivers. 2017, 14, e1600340. [CrossRef] [PubMed]

24. Nam, A.M.; Casanova, J.; Tomi, F.; Bighelli, A. Composition and chemical variability of Corsican Pinus halepensis cone oil. Nat. Prod. Commun. 2014, 9, 1361-1364. [CrossRef] 
25. Byers, J.A. Chemical Ecology of Insects 2; Chapman and Hall: New York, NY, USA, 1995; pp. 154-213.

26. Salem, M.Z.M.; EL-Hefny, M.; Ali, H.M.; Elansary, H.O.; Nasser, R.A.; El-Settawy, A.A.A.; El Shanhorey, N.; Ashmawy, N.A.; Salem, A.Z.M. Antibacterial activity of extracted bioactive molecules of Schinus terebinthifolius ripened fruits against some pathogenic bacteria. Microb. Pathogen. 2018, 120, 119-127. [CrossRef]

27. Lloyd, H.A.; Jaouni, T.M.; Evans, S.L.; Morton, J.F. Terpenes of Schinus terebinthifolius. Phytochemistry 1977, 16, 1301-1302. [CrossRef]

28. Kassem, M.E.S.; El-Desoky, S.K.; Sharaf, M. Biphenyl esters and bioflavonoids from the fruits of Schinus terebinthifolius. Chem. Nat. Compd. 2004, 40, 447-450. [CrossRef]

29. Lima, M.R.F.; Luna, J.S.; Santos, A.F.; Andrade, M.C.C.; Sant'ana, A.E.G.; Genet, J.P.; Marquez, B.; Neuville, L.; Moreau, N. Anti-bacterial activity of some Brazilian medicinal plants. J. Ethnopharmacol. 2006, 105, 137-147. [CrossRef]

30. Ceruks, M.; Romoff, P.; Fávero, O.A.; Lago, J.H.G. Constituintes fenólicos polares de Schinus terebinthifolius Raddi (Anacardiaceae). Quím. Nova 2007, 30, 597-599. [CrossRef]

31. Degáspari, C.H.; Waszczynskyj, N.; Prado, M.R.M. Atividade antimicrobiana de Schinus terebinthifolius Raddi. Cienc. E Agrotecnol 2005, 29, 617-622. [CrossRef]

32. Braga, F.G.; Bouzada, M.L.; Fabri, R.L.; Matos, M.O.; Moreira, F.O.; Scio, E.; Coimbra, E.S. Antileishmanial and antifungal activity of plants used in traditional medicine in Brazil. J. Ethnopharmacol. 2007, 111, 396-402. [CrossRef]

33. Schmourlo, G.; Mendonça-Filho, R.R.; Alviano, C.S.; Costa, S.S. Screening of antifungal agents using ethanol precipitation and bioautography of medicinal and food plants. J. Ethnopharmacol. 2005, 96, 563-568. [CrossRef]

34. Johann, S.; Sá, N.P.; Lima, L.A.R.S.; Cisalpino, P.S.; Cota, B.B.; Alves, T.M.A.; Siqueira, E.P.; Zani, C.L. Antifungal activity of schinol and a new biphenyl compound isolated from Schinus terebinthifolius against the pathogenic fungus Paracoccidioides brasiliensis. Ann. Clin. Microbiol. Antimicrob. 2010, 9, 30. [CrossRef]

35. Viitanen, H.; Ritschkoff, A.C. Mold Growth in Pine and Spruce Sapwood in Relation to Air Humidity and Temperature; Report No. 221; Swedish University of Agricultural Sciences, Department of Forest Products: Uppsala, Sweden, 1991.

36. Ţura, D.; Wasser, S.P.; Zmitrovich, I.V. Wood-Inhabiting Fungi: Applied Aspects. In Fungi: Applications and Management Strategies; Sunil, K., Deshmukh, J.K., Misra, J.P., Tewari, T.P., Eds.; Chapter: 12; CRC Press: Boca Raton, FL, USA, 2016.

37. Salem, M.Z.M. EDX measurements and SEM examination of surface of some imported woods inoculated by three mold fungi. Measurement 2016, 86, 301-309. [CrossRef]

38. Mansour, M.M.A.; Salem, M.Z.M.; Khamis, M.H.; Ali, H.M. Natural durability of Citharexylum spinosum and Morus alba woods against three mold fungi. BioResources 2015, 10, 5330-5344. [CrossRef]

39. Mansour, M.M.A.; Abdel-Megeed, A.; Nasser, R.A.; Salem, M.Z.M. Comparative evaluation of some woody trees methanolic extracts and Paraloid B-72 against phytopathogenic mold fungi Alternaria tenuissima and Fusarium culmorum. BioResources 2015, 10, 2570-2584. [CrossRef]

40. EL-Hefny, M.; Salem, M.Z.M.; Behiry, S.I.; Ali, H.M. The potential antibacterial and antifungal activities of wood treated with Withania somnifera fruit extract, and the phenolic, caffeine and flavonoid composition of the extract according to HPLC. Processes 2020, 8, 113. [CrossRef]

41. Dayan, F.E.; Cantrell, C.L.; Duke, S.O. Natural products in crop protection. Bioorg. Med. Chem. 2009, 17, 4022-4034. [CrossRef] [PubMed]

42. Tinkeu, L.; Goudoum, S.N.; Ngassoum, A.; Mapongmetsem, M.B.; Kouninki, P.M.; Hance, T. Persistence of the insecticidal activity of five essential oils on the maize weevil Sitophilus zeamais (Motsch.) (Coleoptera: Curculionidae), Commun. Agric. Appl. Biol. Sci. 2004, 69, 145-147.

43. Zhu, J.; Zeng, X.; Ma, Y.; Liu, T.; Qian, K.; Han, Y.; Xue, S.; Tucker, B.; Schultz, G.; Coats, J.; et al. Adult repellency and larvicidal activity of five plant essential oils against mosquitoes. J. Am. Mosq. Control Assoc. 2006, 22, 515-522. [CrossRef]

44. Jaenson, T.G.T.; Garboui, S.; På lsson, K. Repellency of oils of lemon Eucalyptus, Geranium, and Lavender and the mosquito repellent MyggA Natural to Ixodes ricinus (Acari: Ixodidae) in the laboratory and field. J. Med. Entomol. 2006, 43, 731-736. [CrossRef] [PubMed] 
45. US EPA (United States Environment Protection Agency), p-Menthane-3,8-diol (011550) Fact Sheet. 2000. Available online: https://www3.epa.gov/pesticides/chem_search/reg_actions/registration/fs_PC-011550_01Apr-00.pdf (accessed on 21 February 2020).

46. Gardulf, A.; Wohlfart, I.; Gustafson, R. A prospective cross-over field trial shows protection of lemon Eucalyptus extract against tick bites. J. Med. Entomol. 2004, 41, 1064-1067. [CrossRef] [PubMed]

47. Chou, J.T.; Rossignol, P.A.; Ayres, J.W. Evaluation of commercial insect repellents on human skin against Aedes aegypti (Diptera: Culicidae). J. Med. Entomol. 1997, 34, 624-630. [CrossRef] [PubMed]

48. Schwan-Estrada, K.R.F.; Stangarlin, J.R.; Cruz, M.E.S. Uso de plantas medicinais no controle de doenças de plantas. Fitopatol. Bras. 2003, 28, 554-556.

49. Lucas, G.C.; Alves, E.; Pereira, R.B.; Perina, F.J.; de Souza, R.M. Antibacterial activity of essential oils on Xanthomonas vesicatoria and control of bacterial spot in tomato. Pesqui. Agropecuária Bras. 2012, 47, 351-359. [CrossRef]

50. Halfeld-vieira, B.A.; Romeiro, R.S.; Mizubuti, E.S.G. Isolation methods of tomato phylloplane bacteria aiming specific populations and implications as biocontrol agents. Fitopatol. Bras. 2004, 29, 638-643. [CrossRef]

51. Okla, M.K.; Alamri, S.A.; Salem, M.Z.M.; Ali, H.M.; Behiry, S.I.; Nasser, R.A.; Alaraidh, I.A.; Al-Ghtani, S.M.; Soufan, W. Yield, phytochemical constituents, and antibacterial activity of essential oils from the leaves/twigs, branches, branch wood, and branch bark of Sour Orange (Citrus aurantium L.). Processes 2019, 7, 363. [CrossRef]

52. Mansour, M.M.A.; Salem, M.Z.M. Evaluation of wood treated with some natural extracts and Paraloid B-72 against the fungus Trichoderma harzianum: Wood elemental composition, In-vitro and application evidence. Inter. Biodeterior. Biodegrad. 2015, 100, 62-69. [CrossRef]

53. Salem, M.Z.M.; Mansour, M.M.A.; Mohamed, W.S.; Ali, H.M.; Hatamleh, A.A. Evaluation of the antifungal activity of treated Acacia saligna wood with Paraloid B-72/ $/ \mathrm{TiO}_{2}$ nanocomposites against the growth of Alternaria tenuissima, Trichoderma harzianum, and Fusarium culmorum. BioResources 2017, 12, 7615-7627.

54. Salem, M.Z.M.; Zidan, Y.E.; Mansour, M.M.A.; El Hadidi, N.M.N.; Abo Elgat, W.A.A. Evaluation of usage three natural extracts applied to three commercial wood species against five common molds. Int. Biodeterior. Biodegrad. 2016, 110, 206-226. [CrossRef]

55. Salem, M.Z.M.; Zidan, Y.E.; Mansour, M.M.A.; El Hadidi, N.M.N.; Abo Elgat, W.A.A. Antifungal activities of two essential oils used in the treatment of three commercial woods deteriorated by five common mold fungi. Int. Biodeterior. Biodegrad. 2016, 106, 88-96. [CrossRef]

56. NIST/EPA/NIH Mass. Spectral Library (NIST 14) and NIST Mass Spectral Search Program (Version 2.0g) May 2014. Available online: https://www.sisweb.com/software/ms/nist.htm (accessed on 10 January 2020).

57. Abdelsalam, N.R.; Salem, M.Z.M.; Ali, H.M.; Mackled, M.I.; EL-Hefny, M.; Elshikh, M.S.; Hatamleh, A.A. Morphological, biochemical, molecular, and oil toxicity properties of Taxodium trees from different locations. Indu. Crop. Prod. 2019, 139, 111515. [CrossRef]

58. SAS. User Guide: Statistics (Release 8.02); SAS Institute: Cary, NC, USA, 2001.

59. Kozan, E.; Küpeli, E.; Yesilada, E. Evaluation of some plants used in turkish folk medicine against parasitic infections for their in vivo anthelmintic activity. J. Ethnopharmacol. 2006, 108, 211-216. [CrossRef] [PubMed]

60. Senouci, F.; Ababou, A.; Chouieb, M. Ethnobotanical Survey of the Medicinal Plants used in the Southern Mediterranean. Case Study: The Region of Bissa (Northeastern Dahra Mountains, Algeria). Pharmacogn. J. 2019, 11, 647-659. [CrossRef]

61. Pasqualini, V.; Robles, C.; Garzino, S.; Greff, S.; Bousquet-Mélou, A.; Bonin, G. Phenolic compounds content in Pinus halepensis Mill. Needles: A bioindicator of air pollution. Chemosphere 2003, 52, 239-248. [CrossRef]

62. Benouadah, N.; Pranovich, A.; Aliouche, D.; Hemming, J.; Smeds, A.; Willför, S. Analysis of extractives from Pinus halepensis and Eucalyptus camaldulensis as predominant trees in Algeria. Holzforschung 2017, 72, 97-104. [CrossRef]

63. Benouadah, N.; Aliouche, D.; Pranovich, A.; Willför, S. Chemical characterization of Pinus halepensis sapwood and heartwood. Wood Mater. Sci. Eng. 2019, 14, 157-164. [CrossRef]

64. Cheikh-Rouhou, S.; Hentati, B.; Besbes, S.; Blecker, C.; Deroanne, C.; Attia, H. Chemical Composition and Lipid Fraction Characteristics of Aleppo Pine (Pinus halepensis Mill.) Seeds Cultivated in Tunisia. Food Sci. Technol. Int. 2006, 12, 407-415. [CrossRef]

65. El-Shazli, E.M.; Hafezh, S.S.; Abdel-Ghany, A.E. Analysis of the essential oils of S. terebinthifolius Raddi cultivated in Egypt. Zagazig J. Pharm. Sci. 2000, 9, 1-8. 
66. Chowdhury, A.R.; Tripathi, S. Essential oil from leaves of S. terebinthifolius Raddi. Indian Perfum. 2001, 4, 257-259.

67. Barbosa, L.C.A.; Demuner, A.J.; Clemente, A.D.; De Paula, V.F.; Ismail, F.M.D. Seasonal variation in the composition of volatile oils from Schinus terebinthifolius Raddi. Quim. Nova 2007, 30, 1959-1965. [CrossRef]

68. Bendaoud, H.; Romdhane, M.; Souchard, J.P.; Cazaux, S.; Bouajila, J. Chemical composition and anticancer and antioxidant activities of Schinus Molle L. and Schinus terebinthifolius Raddi berries essential oils. J. Food Sci. 2010, 75, 466-472. [CrossRef]

69. Richter, R.; Von Reuß, S.H.; König, W.A. Spirocyclopropane-type sesquiterpene hydrocarbons from Schinus terebinthifolius Raddi. Phytochemistry 2010, 71, 1371-1374. [CrossRef]

70. Cole, E.R.; dos Santos, R.B.; Lacerda Júnior, V.; Martins, J.D.L.; Greco, S.J.; Cunha Neto, A. Chemical composition of essential oil from ripe fruit of Schinus terebinthifolius Raddi and evaluation of its activity against wild strains of hospital origin. Braz. J. Microbiol. 2014, 45, 821-828. [CrossRef]

71. Hussein, H.S.; Salem, M.Z.M.; Soliman, A.M. Repellent, attractive, and insecticidal effects of essential oils from Schinus terebinthifolius fruits and Corymbia citriodora leaves on two whitefly species, Bemisia tabaci and Trialeurodes ricini. Sci. Hortic. 2017, 216, 111-119. [CrossRef]

72. Périno-Issartier, S.; Abert-Vian, M.; Petitcolas, E.; Chemat, F. Microwave turbo hydrodistillation for rapid extraction of the essential oil from Schinus terebinthifolius Raddi berries. Chromatographia 2010, 72, 347-350. [CrossRef]

73. Carvalho, M.G.; Melo, A.G.N.; Aragão, C.F.S.; Raffin, F.N.; Moura, T.F.A.L. Schinus terebinthifolius Raddi: Chemical composition, biological properties and toxicity. Rev. Bras. Plantas Med. (Botucatu) 2013, 15, 158-169. [CrossRef]

74. Santana, J.S.; Sartorelli, P.; Guadagnin, R.C.; Matsuo, A.L.; Figueiredo, C.R.; Soares, M.G.; Da Silva, A.M.; Lago, J.H.G. Essential oils from Schinus terebinthifolius leaves-Chemical composition and in vitro cytotoxicity evaluation. Pharm. Biol. 2012, 50, 1248-1253. [CrossRef] [PubMed]

75. Mohamed, A.A.; Behiry, S.I.; Younes, H.A.; Ashmawy, N.A.; Salem, M.Z.M.; Márquez-Molina, O.; Barbabosa, O.A. Antibacterial activity of three essential oils and five monoterpenes against Ralstonia solanacearum phylotype II isolated from potato. Microb. Pathogen. 2019, 135, 103604. [CrossRef] [PubMed]

76. Dannenberg, G.S.; Funck, G.D.; Silva, W.P.; Fiorentini, Â.M. Essential oil from pink pepper (Schinus terebinthifolius Raddi): Chemical composition, antibacterial activity and mechanism of action. Food Control 2019, 95, 115-120. [CrossRef]

77. Santos, A.C.A.; Rossato, M.; Serafini, L.A.; Bueno, M.; Crippa, L.B.; Sartori, V.C.; Dellacassa, E.; Moyna, P. Efeito fungicida dos óleos essenciais de Schinus molle L. e Schinus terebinthifolius Raddi, Anacardiaceae, do Rio Grande do Sul. Rev. Bras. Farmacogn. 2010, 20, 154-159. [CrossRef]

78. Filipowicz, N.; Kamiński, M.; Kurlenda, J.; Asztemborska, M. Antibacterial and antifungal activity of Juniper Berry oil and its selected components. Phytother. Res. 2003, 17, 227-231. [CrossRef] [PubMed]

79. Helander, I.M.; Alakomi, H.L.; KyostiL, K.; Mattiala-andholm, T.; Pol, I.; Smid, E.J.; Gorris, G.M.; von Wright, A. Characterization of the action of selected essential oil components on Graham-negative bacteria. J. Agric. Food. Chem. 1998, 46, 3590-3595. [CrossRef]

80. Cox, S.D.; Mann, C.M.; Markham, J.L.; Bell, H.C.; Gustafson, J.E.; Warmington, J.R.; Wyllie, S.G. The mode of antimicrobial action of the essential oil of Melaleuca alternifolia (Tea tree oil). J. Appl. Microbiol. 2000, 88, 170-175. [CrossRef]

81. Recio, M.C.; Rios, J.L. A review of some antimicrobial compounds isolated from medicinal plants reported in the literature 1978-1988. Phytother. Res. 1989, 3, 117-125.

82. Karaman, S.; Digrak, M.; Ravid, U.; Ilcim, A. Antibacterial and antifungal activity of the essential oils of Thymus revoltus celak from turkey. J. Ethnopharmacol. 2001, 76, 183-186. [CrossRef]

83. Nedorostova, L.; Kloucek, P.; Kokoska, L.; Stolcova, M.; Pulkraibek, J. Antimicrobial properties of selected essential oils in vapour phase against foodborne bacteria. Food Control 2009, 20, 157-160. [CrossRef]

84. Harborne, J.B. Plant Phenolics; Academic Press: London, UK, 1989; pp. 23-53.

85. Conner, D.E. Naturally occurring compounds. In Antimicrobials in Food, 2nd ed.; Davidson, P.M., Branen, A.L., Eds.; Marcel Dekker, Inc.: New York, NY, USA, 1993; pp. 441-467.

86. Ramos-Nino, M.E.; Ramirez-Rodriguez, C.A.; Clifford, M.N.; Adams, M.R. QSARs for the effect of benzaldehydes on foodborne bacteria and the role of sulphydryl groups as targets of their antibacterial activity. J. Appl. Microbiol. 1998, 84, 207-212. [CrossRef] 
87. Walsh, S.E.; Maillard, J.Y.; Simons, C.; Russell, A.D. Studies on the mechanisms of the antibacterial action of ortho-phthalaldehyde. J. Appl. Bacteriol. 1999, 87, 702-710. [CrossRef]

88. Bisignano, G.; LaganÃ, M.G.; Trombetta, D.; Arena, S.; Nostro, A.; Uccella, N.; Saija, A. In vitro antibacterial activity of some aliphatic aldehydes from Olea europaea L. FEMS Microbiol. Lett. 2001, 198, 9-13. [CrossRef]

89. Herruzo-Cabrera, R.; Uriarte, M.C.; Rey-Calero, J. Antimicrobial effectiveness of $2 \%$ glutaraldehyde versus other disinfectants for hospital equipment, an in vitro test based on germ carriers with a high microbial contamination. Rev. Stomatol. Chir. Maxillofac. 1999, 6, 299-305.

90. Taha, A.S.; Salem, M.Z.M.; Abo Elgat, W.A.A.; Ali, H.M.; Hatamleh, A.A.; Abdel-Salam, E.M. Assessment of the impact of different treatments on technological and antifungal properties of produced Papyrus (Cyperus papyrus L.) sheets. Materials 2019, 12, 620. [CrossRef]

91. Omidbeygi, M.; Barzegar, M.; Hamidi, Z.; Naghdibadi, H. Antifungal activity of thyme, summer savory and clove essential oils against Aspergillus flavus in liquid medium and tomato paste. Food Control 2007, 18, 1518-1523. [CrossRef]

92. Amri, I.; Gargouri, S.; Hamrouni, L.; Hanana, M.; Fezzani, T.; Jamoussi, B. Chemical composition, phytotoxic and antifungal activities of Pinus pinea essential oil. J. Pest Sci. 2012, 85, 199-207. [CrossRef]

93. Lucini, E.I.; Zunino, M.P.; Lopez, M.L.; Zygadlo, J.A. Effect of monoterpenes on lipid composition and sclerotial development of Sclerotium cepivorum Berk. J. Phytopathol. 2006, 154, 441-446. [CrossRef]

94. Cristani, M.; Arrigo, M.; Mandalari, G.; Castelli, F.; Sarpietro, M.G.; Micieli, D.; Venuti, V.; Bisignano, G.; Saija, A.; Trombetta, D. Interaction of four monoterpenes contained in essential oils with model membranes: Implications for their antibacterial activity. J. Agric. Food Chem. 2007, 55, 6300-6308. [CrossRef]

95. Viuda-Martos, M.; Ruiz-Navajas, Y.; Fernandez-Lopez, J.; Perez-Alvarez, J. Antifungal activity of lemon (Citrus lemon L.), mandarin (Citrus reticulata L.), grapefruit (Citrus paradisi L.) and orange (Citrus sinensis L.) essential oils. Food Control 2008, 19, 1130-1138. [CrossRef]

96. Tatsadjieu, N.L.; Jazet, D.P.M.; Ngassoum, M.B.; Etoa, F.X.; Mbofung, C.M.F. Investigations on the essential oil of Lippia rugosa from Cameroon for its potential use as antifungal agent against Aspergillus flavus Link ex Fries. Food Control 2009, 20, 161-166. [CrossRef]

97. Daferera, D.J.; Ziogas, B.N.; Polissiou, M.G. GC-MS analysis of essential oils from some Greek aromatic plants and their fungitoxicity on Penicillium digitatum. J. Agric. Food Chem. 2000, 48, 2576-2581. [CrossRef]

(C) 2020 by the authors. Licensee MDPI, Basel, Switzerland. This article is an open access article distributed under the terms and conditions of the Creative Commons Attribution (CC BY) license (http://creativecommons.org/licenses/by/4.0/). 